"Mircea cel Batran" Naval Academy Scientific Bulletin, Volume XIX - 2016 - Issue 2

The journal is indexed in: PROQUEST / DOAJ / Crossref / EBSCOhost / INDEX COPERNICUS / DRJI / OAJI / JOURNAL INDEX / I2OR / SCIENCE LIBRARY INDEX / Google Scholar / Academic Keys/ ROAD Open Access I Academic Resources / Scientific Indexing Services / SCIPIO / JIFACTOR

\title{
GOOD PRACTICE EXAMPLE: DESIGNING 100KN DELTA EYE PLATE
}

\author{
Adrian POPA ${ }^{1}$ \\ Marian RISTEA ${ }^{2}$ \\ Ionut-Cristian SCURTU ${ }^{3}$ \\ Daniel MARASESCU ${ }^{4}$
}

${ }^{1}$ Assist prof. PhD Eng. "Mircea cel Batran" Naval Academy

${ }^{2}$ Assist. prof. PhD. Eng., Marine Engineering and Naval Weapons Department

${ }^{3}$ Principal Instructor, PhD Eng. "Mircea cel Batran" Naval Academy

${ }^{4} \mathrm{PhD}$ attendee "Mircea cel Batran" Naval Academy, Marine Engineering and Naval Weapons Department

Abstract: This article is presenting the steps carried for the design process of a $100 \mathrm{KN}$ delta eye plate, which is a simple but important element used in different setups for offshore installation, by using CAD/CAE methods applied on ANSYS 12.1 Workbench.

Keywords: CAD/CAE, shear stress, distortion.

A general single towing arrangements consists in:

A short pennant - the connection from tug to delta eye plate

- $\quad$ One delta eye plate

- Two bridles (from delta eye plate to the vessel sides)

- Two chafing chains from the bridles to the tow connections

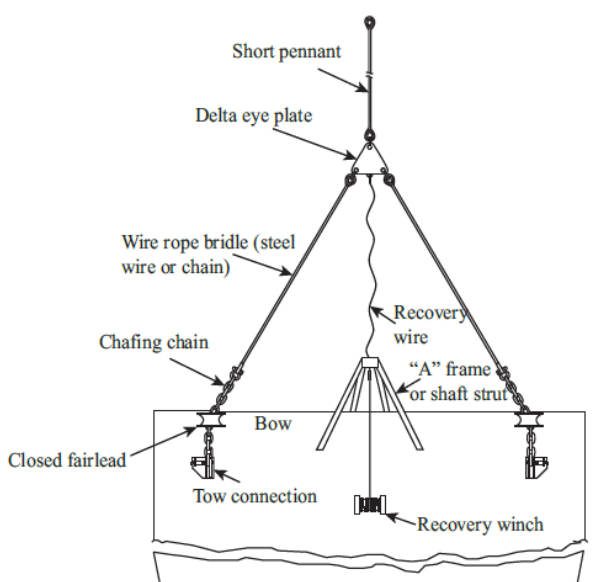

Figure 1 A typical pulling arrangements (Referinta)

One of the key points of the tugging arrangements, is the delta eye plate.

In this plate it is concentrated the tug force and it is distributed on the vessel sides.

In this paperwork we will present the designing steps for a 100KN delta eye plate, using CAD/CAE methods on ANSYS 12.1 Software.

First of all, it is necessary to create the geometric model of the plate.

In a $221 \mathrm{~mm}$ equilateral triangle we are drawing another 100mm equilateral triangle. The big

DOI: 10.21279/1454-864X-16-12-040 triangle represents the delta eye plate and the small triangle corners represent the center of $3 \times 40 \mathrm{~mm}$ holes.

The delta eye plate have $40 \mathrm{~mm}$ thickness

The $221 \mathrm{~mm}$ triangle corners are blended at a $35 \mathrm{~mm}$ radius.

The delta eye plate looks like in figure:

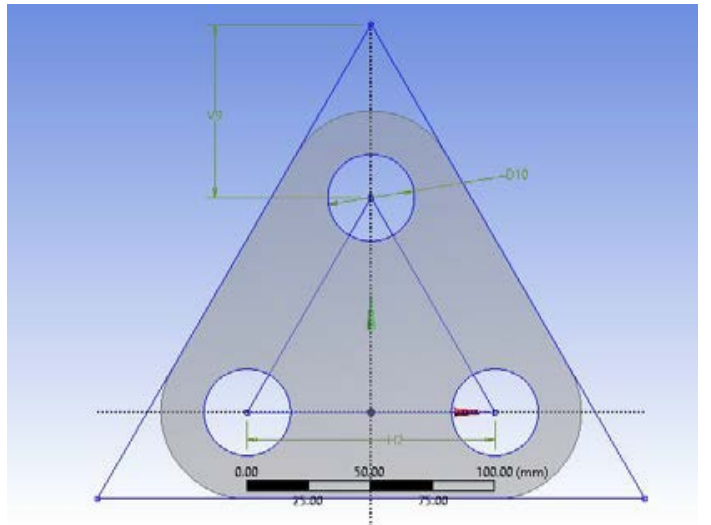

Figure 2 Side view of the $100 \mathrm{KN}$ delta eye plate

Isometric view of the delta eye plate:

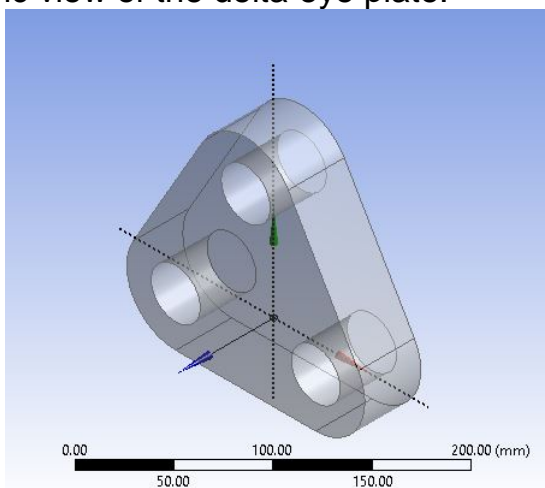

(c) 2015. This work is licensed under the Creative Commons Attribution-Noncommercial-Share Alike 4.0 License. 
"Mircea cel Batran" Naval Academy Scientific Bulletin, Volume XIX - 2016 - Issue 2 The journal is indexed in: PROQUEST / DOAJ / Crossref / EBSCOhost / INDEX COPERNICUS / DRJI / OAJI I JOURNAL INDEX / I2OR / SCIENCE LIBRARY INDEX / Google Scholar / Academic Keys/ ROAD Open Access I Academic Resources / Scientific Indexing Services / SCIPIO / JIFACTOR

\section{Figure 3 Isometric view of the $100 \mathrm{KN}$ delta eye plate}

In practice, the delta eye plate must be realized at it was described, using AH36 structural steel plate.

For the structural analysis during towing, there were added $40 \mathrm{~mm}$ pins in the holes.

The entire ensemble looks like below:

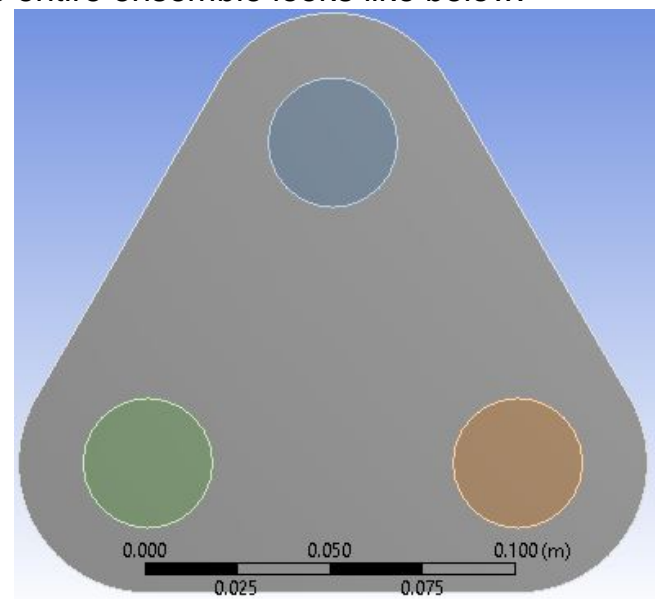

Figure 4 Side view of the towing arrangements

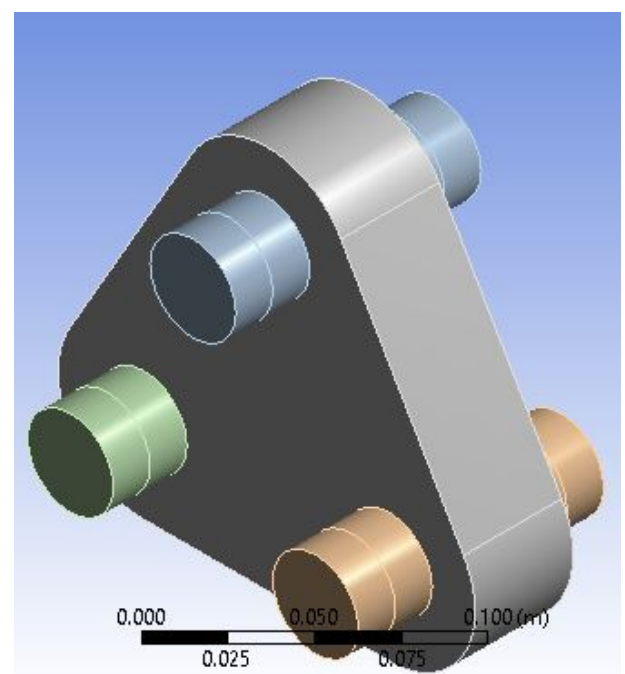

Figure 5 Isometric view of the towing arrangements

The next step in designing the plate is meshing. Mesh characteristics are presented below:

Details of "Mesh"
\begin{tabular}{|l|l|}
\hline Defaults \\
\hline Physics Preference & Mechanical \\
\hline$\square$ Relevance & 100 \\
\hline Sizing & \\
\hline Use Advanced Size Fun... & Off \\
\hline Relevance Center & Coarse \\
\hline$\square$ Element Size & $5 . e-003 \mathrm{~m}$ \\
\hline Initial Size Seed & Active Assembly \\
\hline Smoothing & Medium \\
\hline Transition & Fast \\
\hline Span Angle Center & Coarse \\
\hline Minimum Edge Length & $4 . e-002 \mathrm{~m}$ \\
\hline
\end{tabular}

Figure 6 Details of the mesh

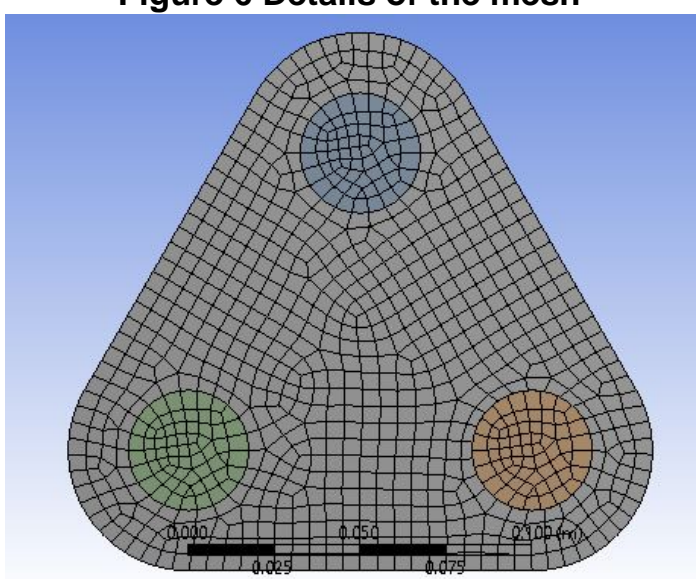

Figure 7 Side view of the mesh structure

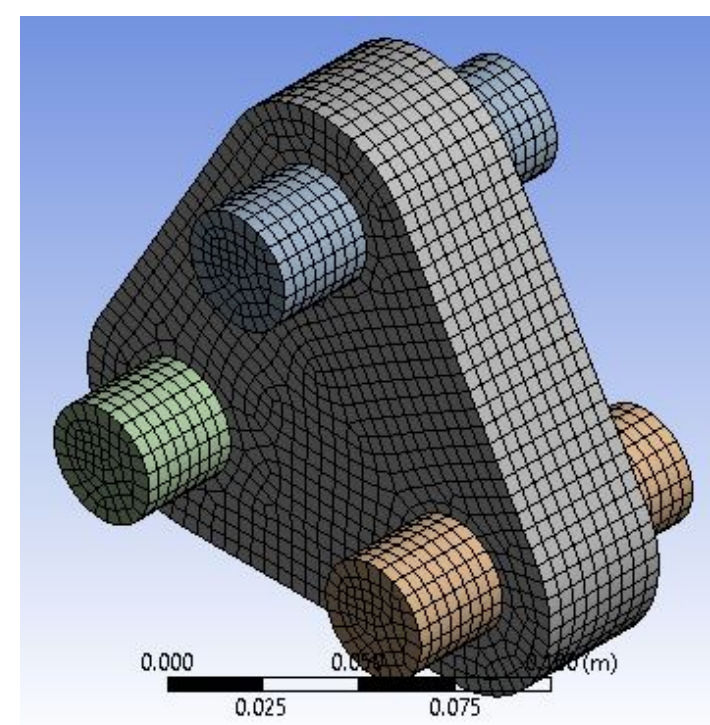

Figure 8 Isometric view of the mesh structure

The mesh consists in 52192 nodes and 11160 elements.

After meshing, the next step consists in setting up the boundary conditions which are:

- Earth gravity is active,

- The $100 \mathrm{KN}$ force acts on one of the bolts, on the OY direction

- The other are two bolts are fixed. 
"Mircea cel Batran" Naval Academy Scientific Bulletin, Volume XIX - 2016 - Issue 2

The journal is indexed in: PROQUEST / DOAJ / Crossref / EBSCOhost / INDEX COPERNICUS / DRJI / OAJI / JOURNAL INDEX I I2OR / SCIENCE LIBRARY INDEX I Google Scholar / Academic Keys/ ROAD Open Access I Academic Resources / Scientific Indexing Services / SCIPIO / JIFACTOR

Boundary conditions are presented in following picture:

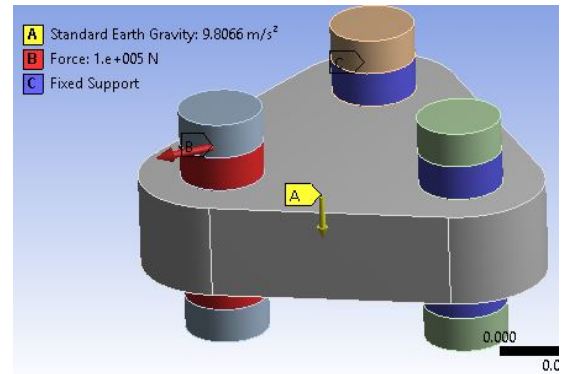

Figure 9 Boundary conditions

Last step is the structural check.

Results of the structural check are presented bellow:

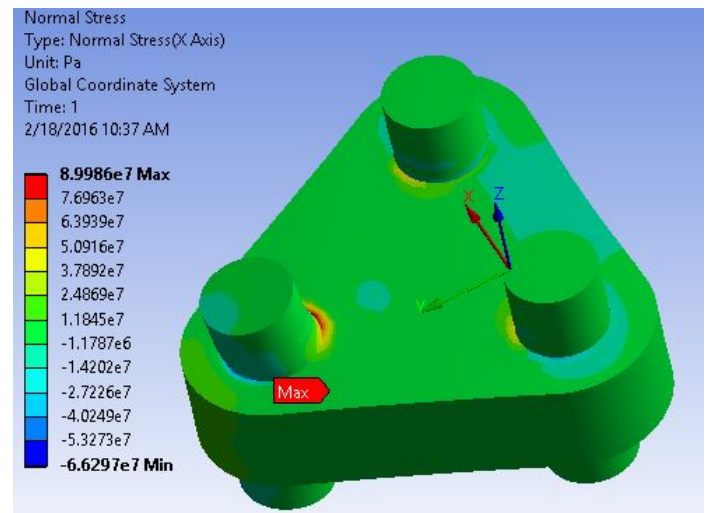

Figure 10 Normal Stres on $\mathrm{X}$ axis

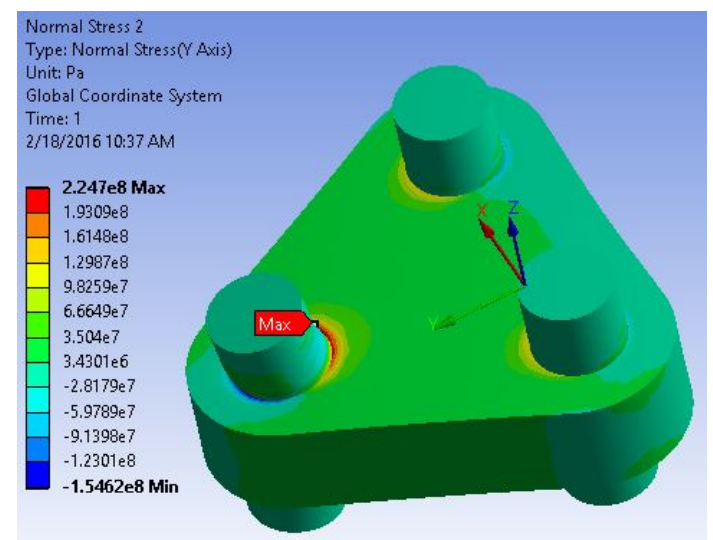

Figure 11 Normal Stres on $\mathrm{Y}$ axis

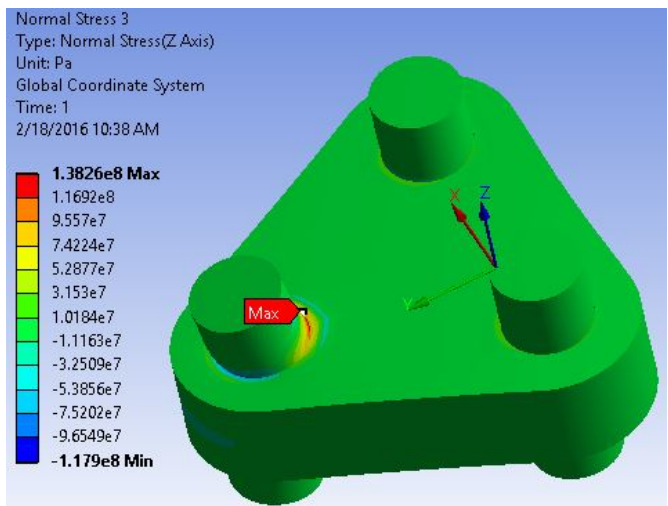

Figure 12 Normal Stres on $Z$ axis

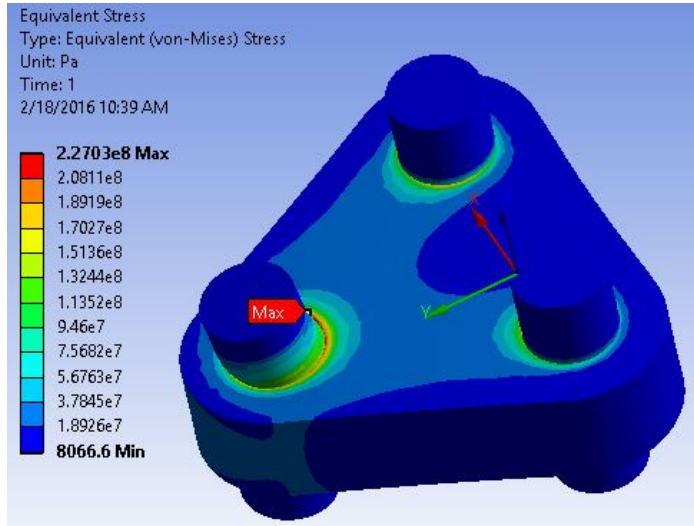

Figure 13 Equivalent Stres

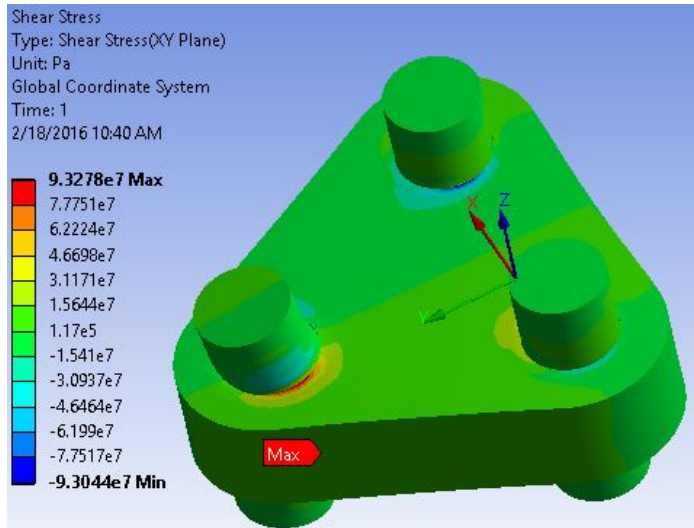

Figure 14 Shear Stress (XY Plane) 
"Mircea cel Batran" Naval Academy Scientific Bulletin, Volume XIX - 2016 - Issue 2 The journal is indexed in: PROQUEST / DOAJ / Crossref / EBSCOhost / INDEX COPERNICUS / DRJI / OAJI I JOURNAL INDEX I I2OR / SCIENCE LIBRARY INDEX / Google Scholar / Academic Keys/ ROAD Open Access I Academic Resources / Scientific Indexing Services / SCIPIO / JIFACTOR

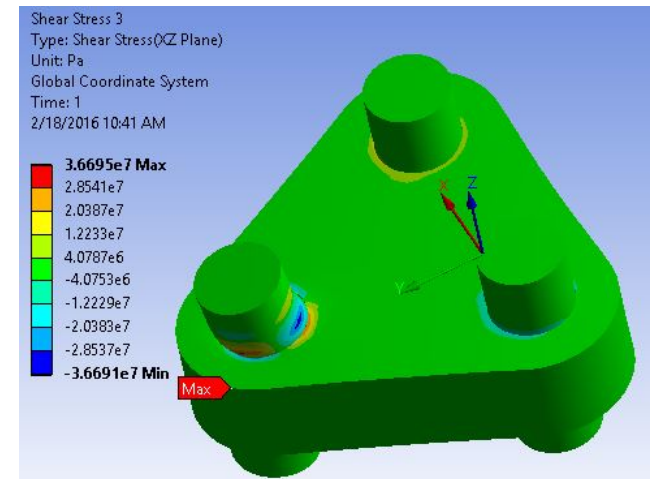

Figure 15 Shear Stress (XZ Plane)

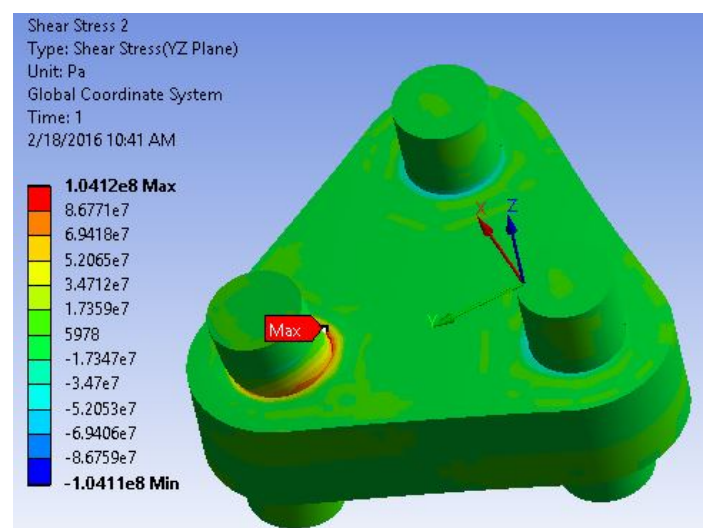

Figure 16 Shear Stress (YZ Plane)

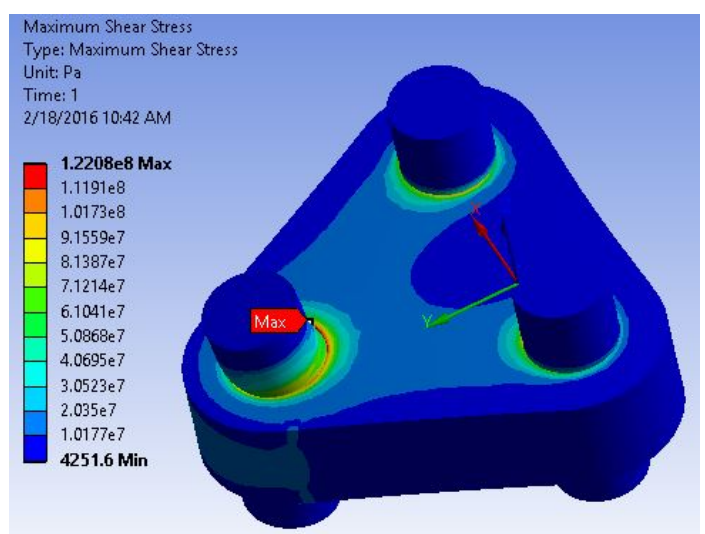

Figure 17 Shear Stress

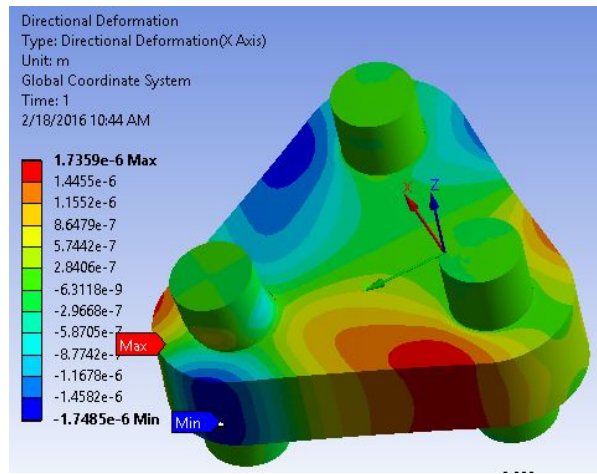

Figure 18Deformations on X Axis

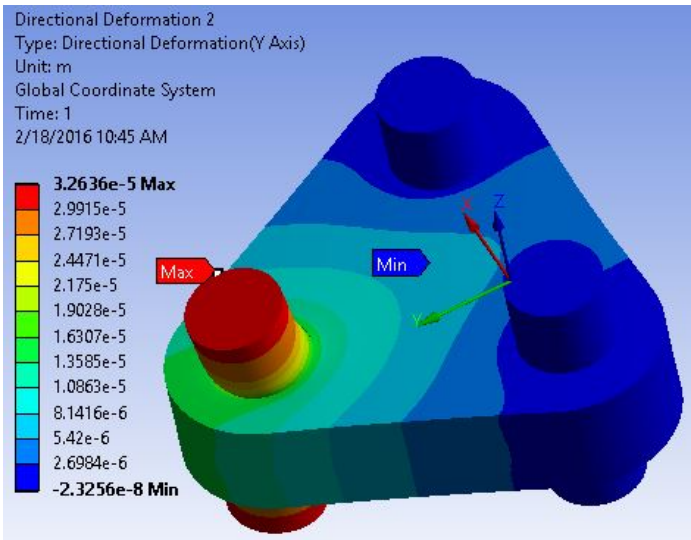

Figure 19 Deformations on Y Axis

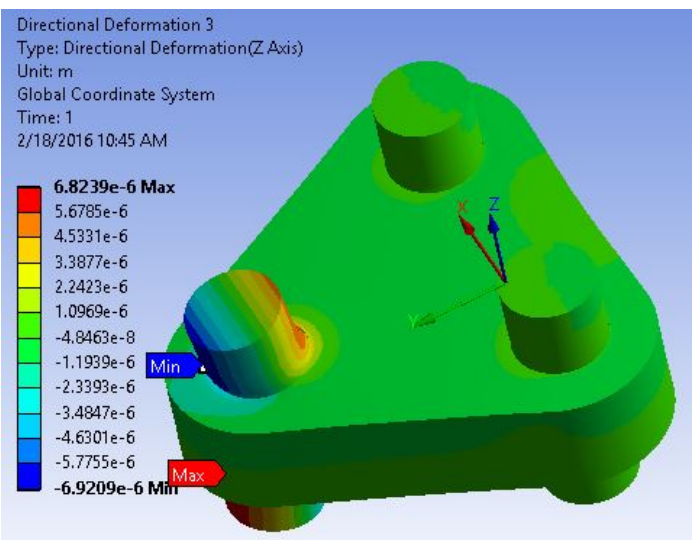

Figure 20 Deformations on Z Axis

The AH36 structural steel have the elastic limit at $355 \mathrm{~N} / \mathrm{mm}^{2}$ (3.55E8 $\mathrm{Pa}$ ). The maximum equivalent stress at this plate, having the design force on one bolt, is at about $63.9 \%$ of this limit, which is accepted by all the classification societies.

\section{BIBLIOGRAPHY}

[1] Ansys Workbench User Manual

[2] Huei - Huang Lee, Finite Element Simulations with Ansys Workbench 12, Schroff Development Corporation, ISBN 978-1-58503-604-2, 2010, 
"Mircea cel Batran" Naval Academy Scientific Bulletin, Volume XIX - 2016 - Issue 2 The journal is indexed in: PROQUEST / DOAJ / Crossref / EBSCOhost / INDEX COPERNICUS / DRJI / OAJI I JOURNAL INDEX I I2OR / SCIENCE LIBRARY INDEX / Google Scholar / Academic Keys/ ROAD Open Access I Academic Resources / Scientific Indexing Services / SCIPIO I JIFACTOR

[3] Moaveni Saeed, Finite Element Analysis: Theory and applications with Ansys, 3rd edition, ISBN978-0-13189080-0, 2008

[4] O.C. Zienkiewicz, R.L. Taylor, The Finite Element Method for Solid and Structural Mechanics, 6th Edition, ISBN 0-7506-6321-9, 2005 